\title{
Diverse migratory behaviors of Atlantic halibut (Hippoglossus hippoglossus, L.) based on the 2000-2017 Maine halibut tagging program
}

\author{
Michael Kersula ${ }^{1}$ and Andrew Seitz ${ }^{2}$ \\ ${ }^{1}$ Department of Marine Resources, State of Maine \\ michael.e.kersula@maine.gov \\ ${ }^{2}$ College of Fisheries and Ocean Sciences, University of Alaska Fairbanks \\ acseitz@alaska.edu
}

\begin{abstract}
KERSULA, M., and A. SEITZ. Diverse migratory behaviors of Atlantic halibut (Hippoglossus hippoglossus, L.) based on the 2000-2017 Maine halibut tagging program. J. Northw. Atl. Fish. Sci., 50: 13-24. https://doi.org/10.2960/J.v50.m719
\end{abstract}

\begin{abstract}
Accurately delineating the spatial extent of fish stocks and the degree to which stocks mix is important for understanding the effects of fisheries management and environmental change. This paper describes migratory behaviors of Atlantic halibut (Hippoglossus hippoglossus L.) tagged with conventional wire tags in the U.S. portion of the Gulf of Maine between 2000 and 2017. There were 412 recaptures reported out of 2573 releases, a return rate of $16.0 \%$. These returns illustrate that although most fish are recaptured close to the release point with a median distance at recapture of $38 \mathrm{~km}$, Gulf of Maine Atlantic halibut also engage in dispersive behavior with some fish travelling at least $1564 \mathrm{~km}$. Returns from Canadian waters accounted for $43.2 \%$ of total recaptures. A generalized linear model found greater distances at recapture related to greater days at liberty and during winter. Fish size explained a negligible proportion $(<1 \%)$ of the variability in recapture distance. Most $(76 \%)$ recaptures were from waters of the Gulf of Maine and the Western Scotian Shelf off Canada, suggesting a higher level of mixing within this transnational boundary area than to elsewhere. This contrasts common assumptions about stock structure made for assessment and management purposes.
\end{abstract}

Keywords: partial migration, halibut, hippoglossus, tagging, Gulf of Maine

\section{Introduction}

A key assumption when defining a fish stock is that the spatial bounds described for the stock reflect actual behavioral phenomena related to distribution so that fisheries science and regulation within those boundaries produce meaningful results. Recent advances in technology related to genetics and electronic tagging (Hauser and Carvalho, 2008; Seitz et al., 2017) have shown that many fish populations are in fact metapopulations (sensu Kritzer and Sale, 2004) comprised of smaller, local units within which demographically meaningful processes occur. Even where stocks are well-defined, there may be multiple "contingents" within a local unit stock, where each contingent displays different migratory behaviors, such as the resident and coastal contingents of the Hudson River striped bass (Morone saxatalis) (Secor, 1999). The presence of multiple contingents, including partial migration, can allow for greater fitness across individuals within a population, but also creates difficulties for traditional fisheries stock assessments that assume closed populations (Kerr et al., 2009). Further complicating assessment, tagging studies for some species such as tunas (Block et al., 2005) and large pelagic sharks (Mejuto et al., 2005) have shown that enough individuals regularly cross ocean basins, hemispheres, and multiple international boundaries to necessitate international cooperation for science and fisheries regulation. If spatial boundaries to delineate a demographically-meaningful stock unit are unknown, understudied, or ignored, the tasks of fisheries assessment and management become less tractable (Stephenson, 1999).

Atlantic halibut (Hippoglossus hippoglossus) is a longlived and commercially important flatfish found across the North Atlantic. We refer to H. hippoglossus as "halibut" for the remainder of this paper. Waters of the United States contain halibut from Cape Cod and Georges Bank into the Gulf of Maine, though there are records of the species present as far south as Virginia (Bigelow and Schroeder, 1953; Cargnelli et al., 1999). The fishery for halibut in the Gulf of Maine has existed for almost two 
centuries. Although at one time they were a nuisance to be avoided on the cod-fishing grounds of the Northwest Atlantic (Bigelow and Schroeder, 1953), a directed fishery for halibut had begun by the 1840s (Grasso, 2008). By the 1880 s, the fishery was effectively over in U.S. and adjacent waters (Goode and Collins, 1887), with the remaining vessels in the fishery having to travel to Iceland to make profitable trips (Grasso, 2008). Over a century later, the U.S. stock is still considered overfished despite recent small increases in a handful of indices (Rago, 2017).

Because they can migrate long $(>1,000 \mathrm{~km})$ distances, currently halibut are considered to belong to a single unit stock in the U.S. (Rago, 2017). In federal waters of the U.S., multispecies groundfish vessels are limited to landing one halibut per trip as non-targeted bycatch by gillnet and otter trawl vessels, with all other halibut discarded. These vessels catch halibut throughout the year (Portland Fish Exchange, 2019). The State of Maine allows a targeted longline fishery in the months of May and June within state waters (out to 3 miles), with a 250 hook per vessel limit, a yearly limit of 25 fish per vessel, and hook size limits (Maine Department of Marine Resources, 2018). Federal waters catches have fluctuated between 47.8 and $60.7 \mathrm{mt}$ from 2012 to 2016, while Maine's state waters longline catch has increased from 13.3 to $47.9 \mathrm{mt}$ during the same time (New England Fisheries Management Council, 2017).

Across the U.S./Canada transnational boundary in the Gulf of Maine known as the Hague Line, the Scotian Shelf and Southern Grand Banks stock assessed by the Department of Fisheries and Oceans (DFO) Canada is at high biomass levels and continues to experience high recruitment (Trzcinski and Bowen 2016; DFO 2018). This disparity in status between adjacent stocks, one certified as sustainable by the Marine Stewardship Council and the other considered overfished, has been hypothesized to be in part due to a separation of the U.S. and Canadian stocks. This hypothesis is supported by electronic tag data (Seitz et al., 2016) and consistent differences in site occupancy of available modeled habitat (Shackell et al., 2016). Specifically, continued low biomass levels of U.S. halibut may support this hypothesis of a separation of stocks, as U.S. fish do not appear to be limited by habitat availability and yet are consistently less abundant on the U.S. side, despite extensive Canadian recovery (Shackell et al., 2016).

As Atlantic halibut recovers in the Northwest Atlantic (Trzcinski and Bowen, 2016), understanding the relative proportion, magnitude, and ontogenetic timing of different migratory behaviors will be important for understanding the dynamics of stocks both within (Boudreau et al.,
2017) and across (Shackell et al., 2016) the exclusive economic zones of Canada and the U.S. For Atlantic halibut, management at too great of a scale may result in persistent localized depletions (Boudreau et al., 2017), and serial depletion of halibut stocks in the northwest Atlantic has happened before (Grasso, 2008). Therefore, the objectives of this study are twofold: 1) to examine the types of migratory behaviors Gulf of Maine halibut display, 2) to examine whether there are ontogenetic or seasonal effects on movement. To address these objectives to the extent possible, this study looks at recaptures from Atlantic halibut tagged in the Gulf of Maine using conventional wire tags over the period 2000-2017.

\section{Methods}

\section{Data and sample collection}

This study reports on 412 reported recaptures through January 2018 from 2573 Atlantic halibut tagged and released in the Gulf of Maine between 2000 and 2017. The State of Maine's Department of Marine Resources began a conventional halibut tagging program as part of an experimental longline fishery that occurred in federal waters off eastern Maine between 2000 and 2004 (Kanwit, 2007). A total of 844 fish smaller than the minimum size at the time, 36 inches $(91.4 \mathrm{~cm})$, was tagged by onboard observers or participating fishermen and released.

Following the success of the tagging from this initial program, the Department expanded the conventional tagging program to the state waters directed fishery and regional fisheries surveys. At public meetings, the Department distributed tags and tag applicator needles, and concurrently trained halibut fishermen on how to tag fish and record pertinent data. Through state waters commercial fishermen, another 1290 sublegal fish were reported as tagged during 2001-2016. As the minimum size was increased to 41 inches $(104.1 \mathrm{~cm})$, the size of tagged fish increased. Additional stakeholder groups were trained to perform tagging, leading to a further 271 tagged fish of all sizes that were released by the Maine/New Hampshire inshore trawl survey from 2001 through 2013, and 45 released by a 2007-2008 halibut longline survey in federal waters off coastal Maine. Other participants included the Massachusetts trawl survey, the Gulf of Maine cod tagging program, and federallypermitted commercial multispecies fishermen, who collectively tagged an additional 123 fish. Maine state waters commercial fishermen recaptured 27 tagged fish that were still under the legal size, and these subsequently re-released fish were recorded as both a recapture and a release. Federal fishery harvesters did not report any re- 
release of juvenile fish or discarding of tagged legal fish released due to their one fish limit. Most tagging occurred during the Maine state commercial halibut season of May and June, regardless of stakeholder. All but eight $(0.3 \%)$ of the releases occurred within 24 miles of the coast of the state of Maine, with the majority of tagged fish released within or adjacent to Maine state waters in the eastern half of the state where the state waters commercial fishery is concentrated. Thus, the primary tagging area was adjacent to Canadian waters, and the median distance for all releases from the U.S.-Canadian maritime boundary was $72 \mathrm{~km}$.

During tagging, fish length was recorded and a stainlesssteel tag coated with yellow plastic was inserted through the outside of the first operculum using a purpose-built applicator needle, with the tag ends then twisted to form a loop. The spaghetti tags used in this program were $16 \mathrm{~cm}$ in total wire length with $14 \mathrm{~cm}$ of the central portion coated in clear plastic, the most central $7.5 \mathrm{~cm}$ in yellow plastic. The plastic was inscribed with "H00001 Return to DMR // PO Box 8 W Boothbay Hbr, ME 04575 PH: 207-633-9535." From 2000 to 2001, deployed tags were manufactured by Floy Tag Inc. From 2002 to present, deployed tags were made by Hallprint Pty Ltd.

To encourage the reporting of recaptures, the Department instituted a reward program for returned tags, providing the returnee with a hat or coffee mug and a letter with information on the tagging program and where and when their fish was released. As tags were returned, a Department employee would reach out to the returnee and attempt to gather any missing biological or spatiotemporal information on the recapture. We did not investigate what percentage of tags from recaptured fish were ultimately reported, or the shedding rate of tags.

\section{Data quality control}

To be included for data analyses, tag recaptures were screened in a quality control process. Out of the 412 recaptures, only 378 included spatial and temporal information of what was determined to be adequate quality, while 351 also included high quality release length information. The analysis in this paper therefore made use of either the subset of 378 or 351 recaptures, as appropriate. None of the recaptures for the 35 tags that we do not describe were from outside of the general recapture area reported in the results.

Many returns had land masses between the points of release and recapture, including smaller islands but also Newfoundland and Nova Scotia. Distance was therefore calculated as the shortest path between points travelling only via ocean waters. To determine ocean-only distance, we first created a 1000 by 1000 cell raster within the spatial extent of the tag releases and recaptures. A highdefinition raster of coastal landmasses within the extent was used to assign costs to cells, with land and a land buffer of $1 \mathrm{~km}$ assigned a value of 999 and ocean a value of 1 . We then determined the least-cost path using the shortest path function from the gdistance package (van Etten, 2018). Due to the size of the cells, precision of computed distances is limited to $0.56 \mathrm{~km}$.

\section{Analysis of seasonal effects}

To determine whether minimum distance travelled between release and recapture locations was related to season, time of recapture was assigned to two seasons and season was incorporated as a two-level factor into a generalized linear model (GLM) described below. Seasons were split into winter (October to March) and summer (April to September) based on the presumed winter spawning period in Canada (Neilson et al., 1993; Armsworthy et al., 2014; Murphy et al., 2017) and a summer foraging period (Godo and Haug, 1988a; Le Bris et al., 2018). To ensure that this analysis examined comparisons of summer releases to summer or winter recaptures, we removed 10 recaptures from analysis that were from fish released in winter months.

\section{Analysis of ontogenetic effects}

To examine whether there were possible ontogenetic effects on minimum distance, the relationship between release length against distance travelled was incorporated into the GLM described below. For comparability to two previous Canadian conventional tagging studies in adjacent waters (Stobo et al., 1988; den Heyer et al., 2012), movement by fish both under and over $80 \mathrm{~cm}$ total length, the L50 for Gulf of Maine male halibut, were compared (Sigourney et al., 2006) using a one-way ANOVA with no assumption of equal variances. In addition, the effect of overall days at liberty on distance was examined as a rough proxy for ontogenetic development as part of the GLM.

\section{Generalized linear model design}

To examine potential drivers of movement, seasonal, size and time-at-liberty factors were included in regression analysis to determine if these were related to movement (defined here as ocean-only distance at recapture in $\mathrm{km}$ ) based on the subset of data with high quality spatial, temporal, and release length information, from summer 
releases $(n=341)$. An initial multiple regression using fish length at release, days at liberty, and season as explanatory variables failed a Shapiro-Wilk normality test of the residuals $\left(p<2.2 \mathrm{e}^{-16}\right)$. To aid in resolving issues with the error distribution, we built a generalized linear model (GLM) to better accommodate the error structure around the response variable. With the continuous, positive response variable of distance we chose a Gamma distribution with a log link for the GLM as most appropriate (Quinn and Keough, 2009). We included as predictors in the model days at liberty, fish length at release, and season of recapture. Because seasonal fish movement could be influenced by maturity, we included an interaction term for release length and season. All explanatory predictors were continuous, except season was a two-level factor consisting of winter and summer (see above). Prior to modeling, the response variable of distance was transformed by adding one meter to remove false zeroes occurring due to imprecise reporting of release and recapture locations when fishermen recaptured fish at the same underwater feature where released.

After building the GLM, we examined relative model fit based on the Akaike Information Criterion (AIC; Akaike 1974). The AIC uses the number of parameters in the model and the maximized value of the model likelihood function to compute an AIC score (Akaike, 1974). For this GLM, the scores served as a basis for comparing explanatory variables in different model formulations based on how much each predictor contributed to the goodness-of-fit against how much complexity each added to the model. We report here on the complete model, as well as a subset of model combinations following AICbased stepwise removals from the stepAIC function in the R package MASS (Venables and Ripley, 2002). For model validation, we looked at the model with the lowest AIC value, and examined fitted values against the Pearson residuals. All data analyses including calculating minimum swimming distance, descriptive statistics and modelling were done in the R statistical software (R Core Project Team, 2018).

\section{Results}

Between April 28, 2000 and August 13, 2017 a total of 2573 Atlantic halibut were tagged and released in the Gulf of Maine. Most releases occurred during 2000-2010, while most recaptures occurred by 2013 (Table 1). Of the tagged fish, length information was available for $97.4 \%$ at release, with mean and median total fish lengths of 78 and $81 \mathrm{~cm}$ (range 22-173 cm), respectively.

By January 2018, there were 412 (16.0\%) reported recaptures, including 378 with full location data, 351 with location and release length data, and 320 with full location and growth data (see methods). Of the 378 fish with highquality location recapture data, 332 were tagged in May or June, and 36 were tagged in April, July, August, or September. Only 10 were tagged during October-March. Recapture lengths included 374 records, with a range of 61 to $163 \mathrm{~cm}$, and a mean of $102 \mathrm{~cm}($ median=99 $\mathrm{cm})$. The greatest reported increase in TL for a tagged fish while at liberty was $91 \mathrm{~cm}$. Days at liberty ranged from a few hours to 4433 days (12.1 years). Median days at liberty was 674 , and the mean was 772 days.

\section{Movement}

Distance between release and recapture points ranged from a few meters to 1564 kilometers. Most fish were recaptured close to their release point (Fig. 1), as indicated by a median distance of $38 \mathrm{~km}$, while a number were

Table 1. Number of total releases and recaptures of Atlantic halibut in and adjacent to the Gulf of Maine by year.

\begin{tabular}{cccccc}
\hline \hline Year & Releases & Recaptures & Year & Releases & Recaptures \\
\hline 2000 & 69 & 1 & 2009 & 205 & 50 \\
2001 & 46 & 2 & 2010 & 154 & 36 \\
2002 & 282 & 20 & 2011 & 200 & 27 \\
2003 & 440 & 40 & 2012 & 60 & 21 \\
2004 & 219 & 42 & 2013 & 27 & 22 \\
2005 & 85 & 23 & 2014 & 0 & 8 \\
2006 & 207 & 36 & 2015 & 0 & 7 \\
2007 & 252 & 32 & 2016 & 1 & 4 \\
2008 & 304 & 37 & 2017 & 22 & 4 \\
\hline
\end{tabular}




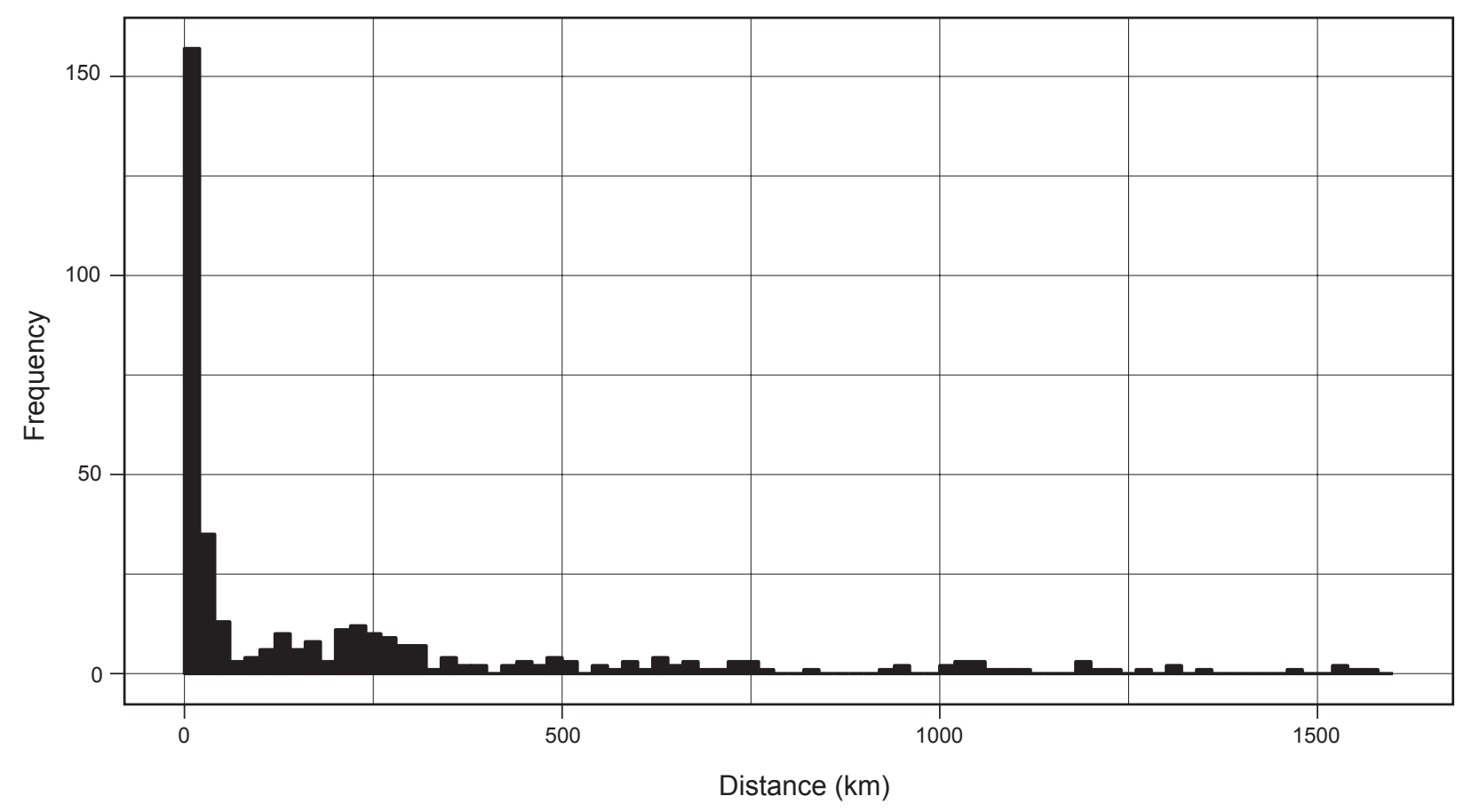

Fig. 1. Histogram of ocean-only swimming distances of Atlantic halibut between release and recapture locations $(n=378)$ in and adjacent to the Gulf of Maine.

recaptured at much greater distances, leading to the larger mean of $219 \mathrm{~km}(1 \mathrm{SD}=338 \mathrm{~km})$. The Canadian fishery recaptured $43.2 \%$ of the tagged fish. Although international emigration was common, a considerable proportion of these halibut were recaptured relatively short distances away in the Bay of Fundy or off southwestern Nova Scotia (Fig. 2). Recaptures west of $65^{\circ}$ West longitude represented $76 \%$ of total returns.

\section{Ontogenetic effects on movement}

Small and large fish were recaptured over a similar range of distances, and fish of all sizes were recaptured close to their release point (Fig. 3). With increasing days at liberty, there were more recaptures at greater distances, however some fish were still recaptured close to the release site across the range of days at liberty (Fig. 4).

\section{Seasonal effects on movement}

Distance at recapture was greater for winter recaptures (median $=317 \mathrm{~km}$; mean $=438 \mathrm{~km} ; n=61$ ) than for summer recaptures ( median $=20 \mathrm{~km}$; mean $=176 \mathrm{~km} ; n=317$ ), with May and June having the lowest median distances (13 and $11 \mathrm{~km}$, respectively), but close to the greatest ranges (1 310 and $1564 \mathrm{~km}$, respectively; Figs. 4,5). Although winter returns had higher median and mean distances, 9 of the
10 largest distance returns were from summer recaptures. Only three of the 61 returns from winter months were from inside U.S. waters (Fig. 2). Returns from winter months included fish reported as captured off the continental slope by the Scotian Shelf, however all but one of the fish recaptured near the slope of the southern Grand Banks were recaptured in summer (Fig. 2).

\section{Generalized linear model}

Based on AIC, the model with the best goodness-of-fit discounted by complexity was the model that included days at liberty, season, and release length (Table 2). Including the interaction term for season and release length in the complete model explained very little $(0.09 \%)$ additional deviance. Release length had a positive effect on distance (Fig. 3) but similarly to the interaction term explained only a small proportion of the deviance when added to the model $(0.57 \%)$. Most of the deviance explained came from the addition to the model of days at liberty $(9.38 \%)$ and season $(5.75 \%)$, both of which had a positive effect on distance (Fig. 4).

Looking at a cutoff roughly similar to that examined in previous studies which looked at fish above and below 75 and $81 \mathrm{~cm}$ TL (Stobo et al., 1988; den Heyer et al., 2012), there were only small differences in recapture distance between fish over $80 \mathrm{~cm}$ total length at release 


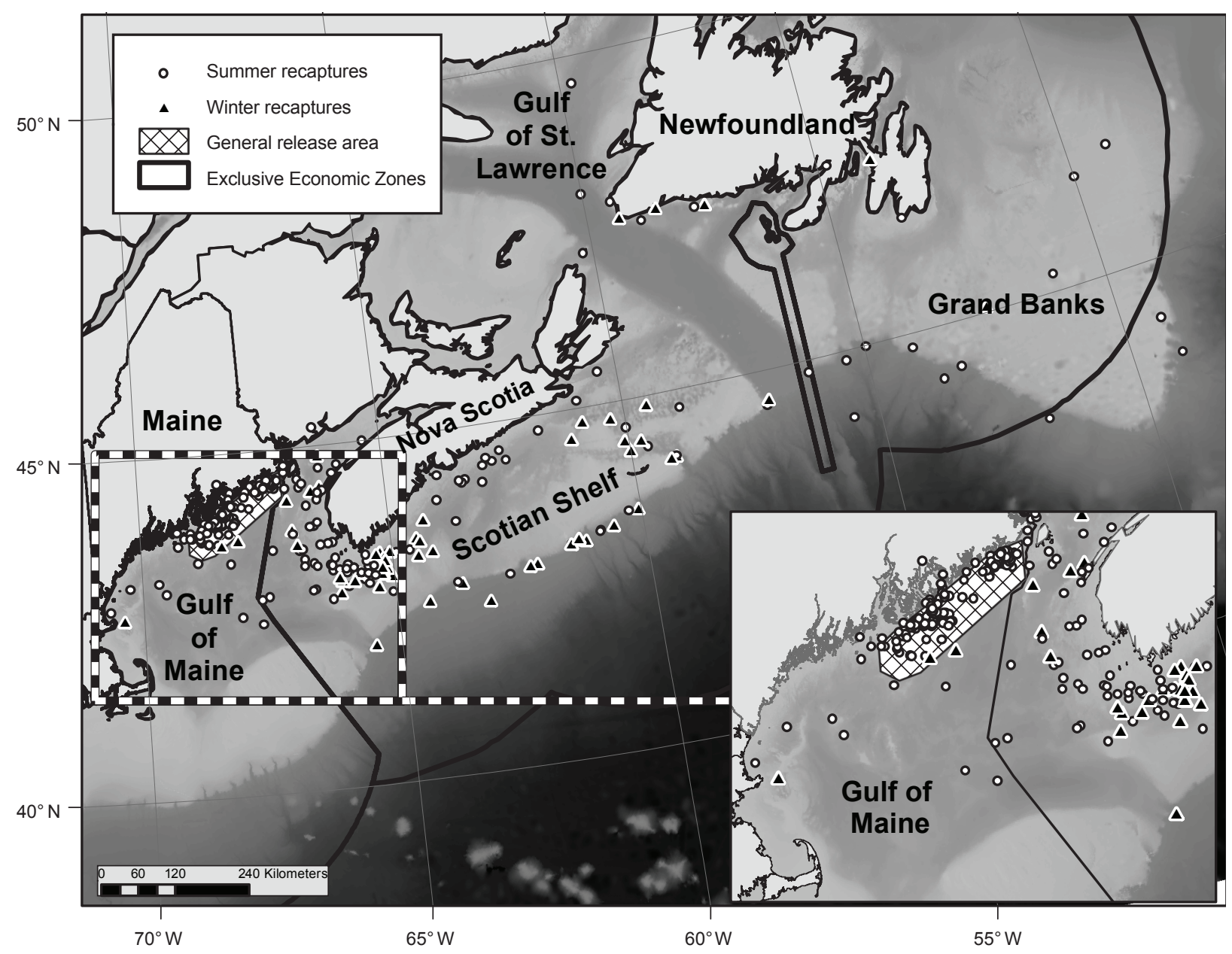

Fig. 2. Recapture locations of Atlantic halibut by season $(n=378)$. Bathymetry data from General Bathymetric Chart of the Oceans. The release area is a general illustration to adhere to State of Maine confidentiality rules.

(median $=29 \mathrm{~km}$; mean $=222 \mathrm{~km} ; n=164)$ and under $80 \mathrm{~cm}$ total length $($ median $=38 \mathrm{~km}$; mean=196 km; $n=187)$, and these were not significant (one-way ANOVA, no assumption of equal variances, $p=0.47$ ).

\section{Discussion}

Atlantic halibut from the Gulf of Maine exhibit a range of migratory behaviors. Although total days at liberty and season in particular may both drive the extent of this movement, fish of all sizes, recaptured at all times of the year and a variety of days at liberty exhibited a range of recapture distances and locations. There is evidence here that halibut tagged in the Gulf of Maine display dispersive behavior and site fidelity, either representing homing or sedentary behavior. This could indicate that if the Gulf of Maine is in fact a discrete population, then multiple contingents (Secor, 1999) are present exhibiting dispersive and site fidelity behaviors, i.e. partial migration (Kerr et al., 2009). Due partially to the short distance required to pass international boundaries from the general release area, a notable proportion of fish was recaptured in the Canadian fishery. Most recaptures of tagged fish occurred within the area stretching from the Gulf of Maine to the Western Scotian Shelf, with limited (24\%) dispersion outside of this area.

The 18-year dataset used in these analyses provides different conclusions from those based on earlier analyses from the first six years of this tagging project. Based on just the returns from 2005 and earlier, Kanwit (2007) reported median days at liberty of 384 days and a median distance travelled of $12 \mathrm{~km}$. Thirteen years later, the median days at liberty is 674 days and median distance is $32 \mathrm{~km}$, suggesting that for long-lived fishes with complex life histories, it may be premature to report on returns without multiple years of data. Additionally, the proportion of tagged fish recaptured outside of the U.S. 
EEZ was $28 \%$ when considering the first six years of data (Kanwit, 2007), but with an additional twelve years of data that number is $43 \%$. These basic findings highlight the value of long-term tagging studies.

\section{Ontogenetic effects}

Ontogenetic development does not appear to be an important factor for driving migratory behavior. The GLM found release length to have a positive effect (Fig. 3), though it explained very little of the deviance in the model (Table 2). In contrast, Stobo and colleagues (1988) found greater movement on the Scotian Shelf and Grand Banks by juveniles, which they defined as less than $75 \mathrm{~cm}$, compared to that of adults and proposed that fish were moving to the northeast as part of a compensatory migration hypothesis in which they were returning to their natal locations to counter drift in their egg and larval stages from spawning grounds to the northeast. However, a more recent study in the same area using a similar size cutoff does not support this hypothesis (den Heyer et al., 2012). The results reported here found no significant difference between fish above and below the L50 cutoff for males in the Gulf of Maine of $80 \mathrm{~cm}$ (Sigourney et al., 2006) when using a simple one-way ANOVA, and furthermore the GLM with release length as a continuous variable found a weak positive effect on swimming distance. The weak, positive effect in the GLM means that the issue is likely not related to using an inaccurate threshold for size-at-maturity for the ANOVA modeling in this or previous studies. At the same time, there is a positive relationship between days at liberty and distance that could point to compensatory migration. Given the lack of a strong size effect, Atlantic halibut in the Gulf of Maine may not exhibit compensatory migration to distant spawning grounds, but rather show general dispersion to adjacent suitable habitat throughout the period of ontogeny represented by tagged fish. The lack of ontogenetic effects in den Heyer's (2012) study promotes this interpretation.

\section{Seasonal effects}

Greater distance at recapture during the winter season could reflect movement to spawning areas on the continental slope, while low summer recapture distances could represent sedentary behavior or homing to summer feeding areas. A mixture of conventional and electronic tagging studies have shown halibut may move to forage in the summer and migrate to spawning grounds in winter, while other fish stay resident (Godo and Haug,

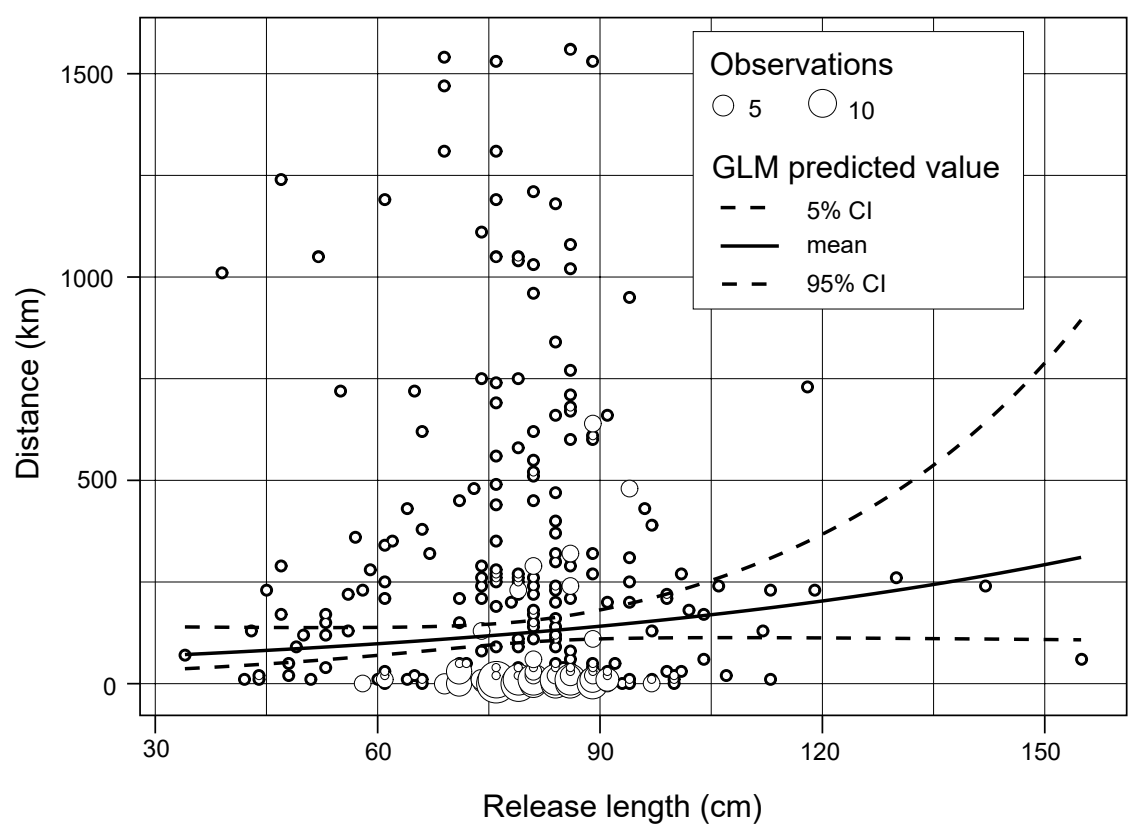

Fig. 3. Ocean-only swimming distance of Atlantic halibut between release and recapture locations in and adjacent to the Gulf of Maine by length of fish at release for tags with complete location and size data $(n=320)$. Lengths have been rounded to the nearest centimeter and distance to the nearest $10 \mathrm{~km}$ for ease of interpretation of the bubble plot. Generalized Linear Model presented here is the model with the best fit, including days at large, season, and release length as predictors. 
1988a, b; Armsworthy et al., 2014; Le Bris et al., 2018; for Hippoglossus stenolepis Nielsen and Seitz, 2017). With most of the fish tagged in this study during summer months, the fish in this study may also have been tagged at a summer feeding location where they were again recaptured, leading to lower mean summer recapture distances (Figs. 2, 4, 5). However, as 9 out of 10 of the recaptures with the greatest distances were from the summer period, it appears that some fish are engaging in dispersive behavior beyond just seasonal movements related to spawning or foraging.

\section{Types of migratory behavior}

The results illustrate that Atlantic halibut tagged off the coast of Maine exhibit a variety of migratory behaviors. It is likely that a sizable proportion of fish from the Gulf of Maine either display site fidelity, disperse, or undertake seasonal movements. Electronic tagging studies with Pacific halibut have shown that fish can occupy release locations at a later time both due to sedentary and homing behavior, and this may relate to whether fish undergo spawning migrations (Loher and Seitz, 2008; Nielsen and Seitz, 2017). Within our data, evidence of site fidelity is shown by the low median distance between release and recapture and the large number of fish recaptured near the release area (Figs. 1,2). However, this study also provides evidence that a portion of Gulf of Maine fish travel long distances, as shown by the large range in distances year-round (Fig. 5). While some fish exhibit site fidelity to the release area in May and June, others are recaptured at the same time over 1000 kilometers distant and may represent permanent emigrants or migrants that do not follow a seasonal pattern (Fig. 5). If fish tagged in the Gulf of Maine do migrate to Canada to spawn in winter, this dispersive behavior could fall under seasonal mixing if fish from multiple feeding areas mix on common spawning grounds (e.g. Le Bris et al. 2018) or year-round emigration to the slope if these fish stay in the proximity of the spawning area once mature (Armsworthy et al., 2014).

This diversity in migratory behaviors by halibut in the Gulf of Maine may indicate that there are multiple contingents present, potentially including residential and migratory (Secor, 1999). If fish that are large enough to be caught by commercial fishing gear are already at a life stage to begin employing one or the other strategy, then the presence of contingents is supported by the existence of fish of all sizes recaptured across the entire range of distances. The finding that days at liberty was a significant variable and explained more deviance than the other variables in the GLM (Table 2; Fig. 4) may suggest that there is a general trend for disperserive behavior to become a more common

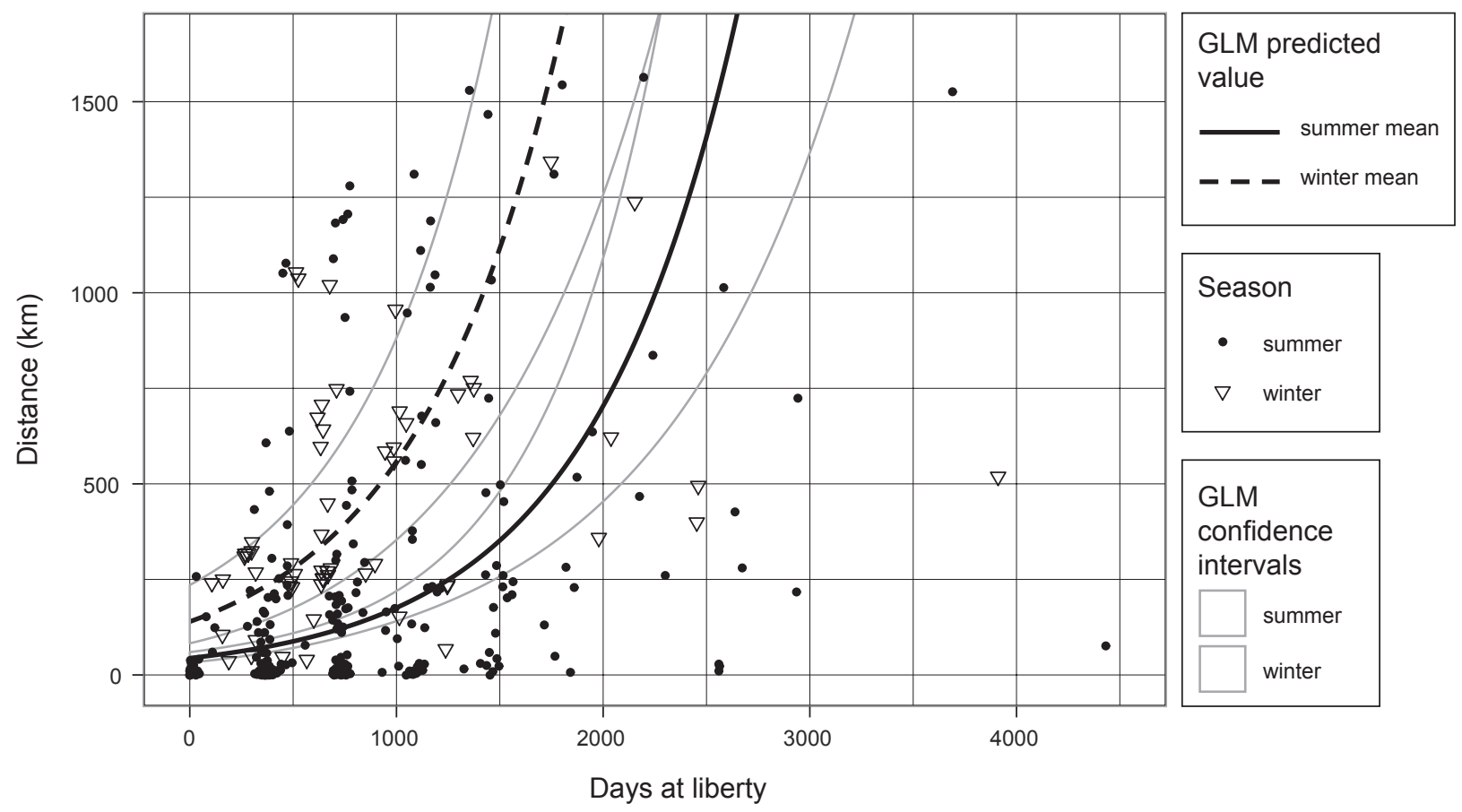

Fig. 4. Ocean-only swimming distance of Atlantic halibut between release and recapture locations in and adjacent to the Gulf of Maine for tags with complete location data $(n=378)$ compared to days at liberty and season of recapture. The Generalized Linear Model presented here is the model with the best fit, including days at large, season, and release length as predictors. 


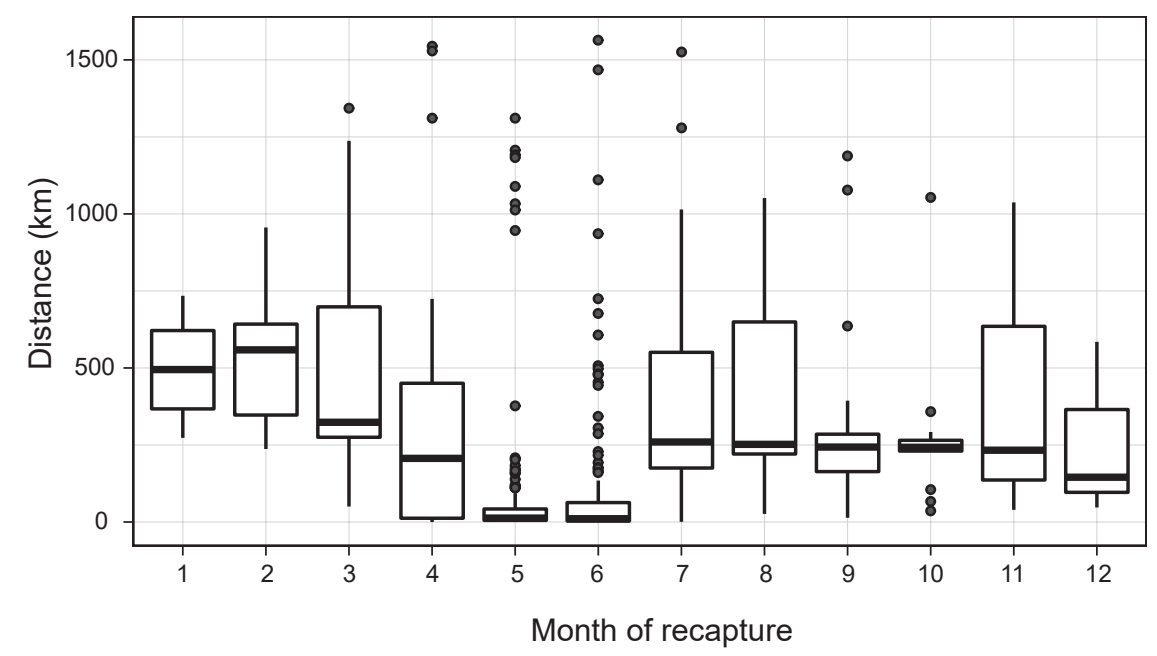

Fig. 5. Boxplots of minimum distance travelled by Atlantic halibut between release and recapture locations in and adjacent to the Gulf of Maine for tags with complete location data $(n=378)$ compared to month of recapture. Note that sample sizes for November, December, and January recaptures are very small $(n=3,3,5$ respectively). Boxplots include median (solid line), interquartile range (hinges), closest point to $1.5 *$ interquartile range (whisker), and outliers (points).

behavior for Atlantic halibut from the Gulf of Maine given enough time, while resident (sedentary and homing) behavior decreases in frequency. The results reported here support the continued persistence of both contingents.

\section{Conventional tagging studies and biases}

The use of conventional tags warrants careful interpretation of results. Recovery of conventional tags depends on capture efforts and subsequent reporting, which when inconsistent over time and space may result in biases (Webster et al., 2013). Therefore, the relatively large proportion of tag returns from Canada since the early 2000s is difficult to interpret as it may reflect greater fishing effort in the targeted Canadian halibut fishery compared to that in U.S. Federal and Maine state waters, rather than a true behavioral phenomenon. Specifically, Canadian landings have increased from a yearly average of $1484 \mathrm{mt}$ in 2000-2009 to $3263 \mathrm{mt}$ in 2016 (DFO, 2018) whereas U.S. catch, consisting mostly of non-target bycatch from the multispecies fishery but also including targeted longline catch from Maine state waters, was $108 \mathrm{mt}$ in 2016 (New England Fisheries Management Council 2017). Alternatively, the increase in recaptures from Canada does agree with the finding that days at liberty has a positive effect on distance at recapture, and the increased timeframe during which recaptures are reported in this study allowed halibut to move into Canadian waters. In addition, as the Hague Line separating U.S. and Canadian waters was only a short distance from most releases the slight increase in median distance at recapture from 12 to $32 \mathrm{~km}$ since the previous study likely has resulted in more fish recaptured across a border that was only a median distance of $72 \mathrm{~km}$ away for tagged and released fish. Any future study that seeks to establish mixing rates between the two jurisdictions will need to estimate fisheries-dependent effects (Webster et al., 2013), as well as reporting rates (Rago, 2017). This work with conventional tags does establish that, at a minimum, $43 \%$ of fish released in the U.S. Gulf of Maine are at some time vulnerable to the Canadian fishery, and this could greatly confound a U.S. stock assessment that must estimate discard and fishing mortality (Rago, 2017).

The presence of a seasonal effect on recapture distance adds to the uncertainty over the relative extent of mixing between the U.S. and Canada. As most of the tagged fish were released and recovered in the Maine state waters commercial fishery, which only occurs in May and June, estimates of small distance movement are likely inflated and summer-to-winter recaptures are likely relatively undetected. The U.S. federal waters multispecies fishery does land fish in Maine throughout the year, though landings are generally lower in winter (Portland Fish Exchange, 2019) and most of the effort in this fishery occurs outside of the tagging release area (New England Fisheries Management Council, 2017). This likely leads to inflated estimates of winter movement if some tagged fish did not leave the summer tagging area where they would not be vulnerable to winter recapture. While the 
Table 2. Different formulations and associated AICs and residual deviances for generalized linear models (Gamma distribution, log link) with swimming distance of Atlantic halibut tagged in the Gulf of Maine as response variable. $\mathrm{DAL}=$ Days at liberty.

\begin{tabular}{|c|c|c|c|c|c|}
\hline Model predictors & AIC & $\begin{array}{l}\text { Residual } \\
\text { deviance }\end{array}$ & $\begin{array}{c}\text { Null } \\
\text { deviance }\end{array}$ & $\begin{array}{c}\text { Residual } \\
\text { d.f. }\end{array}$ & Null d.f. \\
\hline NULL & 3897.5 & 1392.3 & 1392.3 & 340 & 340 \\
\hline DAL, Season, Release length, Season: Release length & 3823.1 & 1172.4 & 1392.3 & 336 & 340 \\
\hline DAL, Season, Release length & 3821.6 & 1173.6 & 1392.3 & 337 & 340 \\
\hline DAL, Season & 3822.7 & 1181.6 & 1392.3 & 338 & 340 \\
\hline DAL & 3852.0 & 1261.7 & 1392.3 & 339 & 340 \\
\hline
\end{tabular}

number of returns from Canada could be enhanced by more directed fishing effort overall, the relative magnitude of winter migrations into Canadian waters could also be an underestimate if fish tagged in the Gulf of Maine are more likely to be present in Canadian waters during winter as the directed Canadian fishery is less active in winter months (Themelis and den Heyer, 2015). However, these examples of potential biases, seasonal and otherwise, are neither comprehensive nor conclusive in their direction, and there may be further issues presented by any unknown effects on reporting rates by gear type, season, or year. We would suggest that what appears to be a seasonal effect in these results should not be interpreted beyond providing a clue regarding potential movement patterns. These patterns could be a basis for future studies that can better avoid these biases, such as with electronic tagging (e.g. Le Bris et al., 2018).

\section{Implications for assessment, management}

These results provide evidence that the current management boundary between U.S. and Canadian stocks does not represent a strict population boundary. It is clear from these results that a large proportion of fish tagged in the U.S. waters of the Gulf of Maine spend at least part of their lives in Canadian waters where they are vulnerable to the Canadian fishery. This could reflect the existence of a demographically-meaningful stock boundary extending across the Hague Line, conflicting with current assumptions used for assessment (Rago, 2017; DFO, 2018). Additionally, it appears that a contingent of Gulf of Maine halibut from U.S. waters displays residency there. Data from this study cannot give precise estimates of stock boundaries or mixing rates, but nevertheless do provide evidence that current assumptions surrounding halibut stocks need to be readdressed in both science and management.

If future studies confirm that stock boundaries cross the Hague Line, it is possible to assess and manage Atlantic halibut through a Transboundary Resource Assessment Committee (TRAC), as has been done for eastern Georges Bank cod, haddock, and yellowtail flounder (Martin et al., 2017; Barrett et al., 2017; Legault et al., 2017). Simply incorporating some estimate of mixing may alleviate certain issues with the U.S. assessment, and allow for a formal assessment beyond the current "Plan B" approach (Rago, 2017). However, just as the current unit stocks are not assessed together, they are not surveyed together. Without DFO halibut longline survey coverage in the Gulf of Maine, it may not be plausible to extend their assessment methods to the west (DFO, 2018). The National Marine Fisheries Service bottom trawl survey, which extends to the Western Scotian Shelf, may offer a unified survey for juvenile biomass. Regardless of how a possible cross-boundary stock unit would be assessed and managed, failure to acknowledge the underlying biological population structure occludes the ability to do either, and bears an increased risk of depletion (Boudreau et al., 2017).

In conclusion, this study illustrates that fish tagged in the Gulf of Maine exhibit a spectrum of migratory behaviors including site fidelity and dispersive movements, and this could have ramifications for how we delineate stock boundaries. Fish are recaptured at greater distances in winter and with more days at liberty, but at all sizes, in all seasons, and over the course of days or many years some fish are caught close to the release point while others are caught $1000 \mathrm{~km}$ or more away, suggesting the presence of resident and migratory or exploratory contingents. At an absolute minimum, $43.2 \%$ of fish tagged in the U.S. portion of the Gulf of Maine spend at least some time in Canadian waters. This number is substantially higher than the mixing rate found by Kanwit (2007) when reporting earlier results of this study, underlining the importance of many years of returns for tagging of long-lived fish with complex life histories. Given the high level of fishing mortality in the Canadian fishery for fish released by American fishermen, there is a need for managing the 
fish across international boundaries through the TRAC process (Shackell et al., 2016), as well as potentially at a finer-scale in Canada (Boudreau et al., 2017). Further research into genetic relations among spawning groups sampled during spawning season, as well as young of year fish including those present in the Gulf of Maine (Beaty and Chen, 2017), may help to describe the extent to which metapopulations in the Northwest Atlantic are demographically discrete. In addition, further electronic tagging with finer temporal sampling intervals could help to show if and where fish from the Gulf of Maine and Western Scotian Shelf are spawning and what this means for stock definition.

\section{Acknowledgements}

We would like to thank all the participants who helped to tag halibut in the Gulf of Maine, especially the commercial harvesters who volunteered their time and information to help tag fish, as well as provide returns. We are grateful to two anonymous reviewers, both of whom gave useful, detailed feedback. Funding for this project was provided by the National Marine Fisheries Service Northeast Cooperative Research Program through an award to the Maine Department of Marine Resources, as well as funds from the Maine Department of Marine Resources Halibut Program.

\section{References}

Akaike, H. 1974. Anew look at the statistical model identification. IEEE Transactions on Automatic Control 19: 716-723. https://doi.org/10.1109/TAC.1974.1100705.

Armsworthy, S. L., Trzcinski, M. K., and Campana, S. E. 2014. Movements, environmental associations, and presumed spawning locations of Atlantic halibut (Hippoglossus hippoglossus) in the northwest Atlantic determined using archival satellite pop-up tags. Marine Biology, 161: 645656. https://doi.org/10.1007/s00227-013-2367-5.

Barrett, M. A., Brooks, E. N., and Wang, Y. 2017. Assessment of haddock on Eastern Georges Bank for 2017. TRAC Ref. Doc. 2. URL: http://www.bio.gc.ca/info/intercol/trac-cert/ documents/reports/TSR_2016_02_E.pdf.

Beaty, J., and Chen, Y. 2017. Can back-calculated lengths based on otoliths measurements provide reliable estimates of Atlantic halibut (Hippoglossus hippoglossus) growth in the Gulf of Maine (U.S.A)? Aquaculture and Fisheries, 2: 24-33. https://doi.org/10.1016/j.aaf.2017.01.002.

Bigelow, H. B., and Schroeder, W. C. 1953. Fishes of the Gulf of Maine. Fishery Bulletin of the Fish and Wildlife Service. 53/592. Fishery Bulletin, 74. Available at: http://www.gma. org/fogm/.

Block, B. A., Teo, S. L. H., Walli, A., Boustany, A., Stokesbury, M. J. W., Farwell, C. J., Weng, K. C., Dewar, H., and Williams, T. D. 2005. Electronic tagging and population structure of Atlantic bluefin tuna. Nature, 434: 1121-1127. https://doi.org/10.1038/nature03463.

Boudreau, S. A., Shackell, N. L., Carson, S., and den Heyer, C. E. 2017. Connectivity, persistence, and loss of high abundance areas of a recovering marine fish population in the Northwest Atlantic Ocean. Ecology and Evolution, 7: 9739-9749. https://doi.org/10.1002/ece3.3495.

Cargnelli, L. M., Griesbach, S. J., and Morse, W. W. 1999. Essential fish habitat source document: Atlantic halibut, Hippoglossus hippoglossus, life history and habitat characteristics. NOAA Tech. Mem. NMFS-NE-125.

den Heyer, C. E., Armsworth, A., Wilson, S., Wilson, G., Bajona, L., Bond, S. and Trzcinski, M. K. 2012. Atlantic halibut all-sizes tagging program summary report for 2006 to 2011. Can. Tech. Rep. Fish. Aquat. Sci., 2992. URL: http:// publications.gc.ca/collections/collection_2012/mpo-dfo/ Fs97-6-2992-eng.pdf.

DFO. 2018. Stock status update of Atlantic halibut (Hippoglossus hippoglossus) on the Scotian Shelf and Southern Grand Banks in NAFO Divisions 3NOPs4VWX5Zc. DFO Can. Sci. Advis. Sec. Sci. Resp. 2018/022. URL: http:// publications.gc.ca/collections/collection_2018/mpo-dfo/ fs 70-7/Fs70-7-2018-022-eng.pdf.

Godo, O. R., and Haug, T. 1988a. Tagging and recapture of Atlantic halibut (Hippoglossus hippoglossus) in Norwegian waters. ICES Journal of Marine Science, 44: 169-179. https://doi.org/10.1093/icesjms/44.2.169.

1988b. Tagging and recapture of Atlantic halibut (Hippoglossus hippoglossus L.) on the continental shelves off Eastern Canada, and off Western and Eastern Greenland. Journal of Northwest Atlantic Fisheries Science. 8: 25-31. https:// doi.org/10.2960/J.v8.a3

Goode, G. B., and Collins, J. W. 1887. The halibut fisheries. In:The Fisheries and Fishery Industries of the United States, Section V: The History and Methods of the Fisheries, Vol. 1. Edited by G. B. Goode. Washington, D.C. pp. 3-89.

Grasso, G. M. 2008. What appear limitless plenty: the rise and fall of the nineteenth-century Atlantic halibut fishery. Env. Hist., 13: 66-91. https://doi.org/10.1093/envhis/13.1.66.

Hauser, L., and Carvalho, G. R. 2008. Paradigm shifts in marine fisheries genetics: ugly hypotheses slain by beautiful facts. Fish and Fisheries, 9: 333-362. https://doi.org/10.1111/ j.1467-2979.2008.00299.x.

Kanwit, J. K. 2007. Tagging results from the 2000-2004 federal experimental fishery for Atlantic halibut (Hippoglossus hippoglossus) in the Eastern Gulf of Maine. Journal of Northwest Atlantic Fisheries Science, 38: 37-42. https:// doi.org/10.2960/J.v38.m594.

Kerr, L. A., Secor, D. H. and Piccoli, P. M. 2009. Partial migration of fishes as exemplified by the estuarine-dependent white perch. Fisheries, 34: 114-123. https://doi.org/10.1577/15488446-34.3.114.

Kritzer, J. P., and Sale, P. F. 2004. Metapopulation ecology in the sea: from Levins' model to marine ecology and fisheries science. Fish and Fisheries, 5: 131-140. https:// doi.org/10.1111/j.1467-2979.2004.00131.x.

Le Bris, A., Fisher, J. A. D., Murphy, H. M., Galbraith, P. S., Castonguay, M., Loher, T., and Robert, D. 2018. Migration patterns and putative spawning habitats of Atlantic halibut 
(Hippoglossus hippoglossus) in the Gulf of St. Lawrence revealed by geolocation of pop-up satellite archival tags. ICES Journal of Marine Science, 75: 135-147. https://doi. org/10.1093/icesjms/fsx098.

Legault, C. M., and McCurdy, Q. M. 2017. Stock assessment of Georges Bank Yellowtail Flounder for 2017. TRAC Ref. Doc. 3. URL: https://www.nefsc.noaa.gov/saw/trac/ tsr_2017_gbytail.pdf.

Loher, T., and Seitz, A. C. 2008. Characterization of active spawning season and depth for eastern Pacific halibut (Hippoglossus stenolepis) and evidence of probably skipped spawning. Journal of Northwest Atlantic Fisheries Science, 41: 23-36. https://doi.org/10.2960/J.v41.m617

Maine Department of Marine Resources. 2018. 2018 Compliance guide for Maine state waters halibut fishery regulations. URL: https://www.maine.gov/dmr/science-research/ species/documents/DMR\%20Halibut $\% 20$ Compliance $\% 20$ Guide\%202018.pdf.

Martin, R., Legault, C. M., Wang,Y., and Brooks, E. N. 2017. TRAC Ref. Doc. 1. Available at: https://www.nefsc.noaa. gov/saw/trac/tsr_2017_egbcod.pdf.

Mejuto, J., Garcia-Cortes, B., and Ramos-Cartelle, A. 2005. Tagging-recapture activities of large pelagic sharks carried out by Spain or in collaboration with the tagging programs of other countries. Col. Vol. Sci. Pap. ICCAT, 58: 974-1000. Available at: http://www.iccat.int/Documents/CVSP/ CV058_2005/no_3/CV058030974.pdf.

Murphy, H. M., Fisher, J. A. D., Le Bris, A., Desgagnes, M., Castonguay, M., Loher, T., and Robert, D. 2017. Characterization of depth distributions, temperature associations, and seasonal migrations of Atlantic halibut in the Gulf of St. Lawrence using Pop-up Satellite Archival Tags. Marine and Coastal Fisheries 9: 1-356. https://doi. org/10.1080/19425120.2017.1327905.

Neilson, J. D., Kearney, J. F., Perley, P., and Sampson, H. 1993. Reproductive biology of Atlantic halibut (Hippoglossus hippoglossus) in Canadian waters. Canadian Journal of Fisheries and Aquatic Sciences, 50: 551-563. https://doi. org/10.1139/f93-064

New England Fisheries Management Council. 2017, December 15. Memorandum: Candidate Atlantic halibut OFLs and ABCs for fishing years 2018 to 2020 . Newburyport, Massachusetts: New England Fisheries Management Council. URL: http://s3.amazonaws.com/nefmc.org/ A4_171215-GF-PDT-memo-to-SSC-re-FY2018-FY2020Atlantic-halibut-OFLs-ABCs_corrected.pdf.

Nielsen, J. L., and Seitz, A. C. 2017 . Interannual site fidelity of Pacific halibut: potential utility of protected areas for management of a migratory demersal fish. ICES Journal of Marine Science, 74: 2120-2134. https://doi.org/10.1093/ icesjms/fsx040.

Portland Fish Exchange. 2019. Portland Fish Exchange price and landing tool. Retrieved on 9 January, 2019 from http:// www.pfex.org/price-landing-tool/.

Quinn, G. P., and Keough, M. J. 2009. Experimental Design and Data Analysis for Biologists. Cambridge University Press, New York. 537 pp.

R Core Team. 2018. R: A language and environment for statistical computing. R Foundatin for Statistical Computing, Vienna, Austria. URL: https://www.R-project.org/.

Rago, P. J. 2017. Draft halibut assessment report for 2017 for New England Fishery Management Council. URL: http:// s3.amazonaws.com/nefmc.org/Halibut-Assessment-Reportdraft-12-01-2017.pdf.

Secor, D. H., 1999. Specifying divergent migrations in the concept of stock: the contingent hypothesis. Fisheries Research, 43: 13-34. https://doi.org/10.1016/S0165-7836(99)00064-8.

Seitz, A. C., Evans, M. D., Courtney, M. B., and Kanwit, J. K. 2016. Continental shelf residency by adult Atlantic halibut electronic tagged in the Gulf of Maine. Journal of Northwest Atlantic Fisheries Science 48: 33-40. https://doi. org/10.2960/J.v48.m713.

Seitz, A. C., Farrugia, T. J., Norcross, B. L., Loher, T., and Nielsen, J. L. 2017. Basin-scale reproductive segregation of Pacific halibut (Hippoglossus stenolepis). Fisheries Management and Ecology, 24: 339-346. https://doi. org/10.1111/fme.12233.

Shackell, N.L., Frank, KT., Nye, J. A., and den Heyer, C. E. 2016. A transboundary dilemma: dichotomous designations of Atlantic halibut status in the Northwest Atlantic. ICES Journal of Marine Science, 73: 1798-1805. https://doi. org/10.1093/icesjms/fsw042.

Sigourney, D. B., Ross, M. R., Brodziak, J. and Burnett, J. 2006. Length at age, sexual maturity and distribution of Atlantic halibut, Hippoglossus hippoglossus L., off the Northeast USA. Journal of Northwest Atlantic Fisheries Science, 36: 81-90. https://doi.org/10.2960/J.v36.m574.

Stephenson, R. L. 1999. Stock complexity in fisheries management: a perspective of emerging issues related to population sub-units. Fisheries Research, 43: 247-249. https://doi.org/10.1016/S0165-7836(99)00076-4.

Stobo, W. T., Neilson, J. D., and Simpson, P. G. 1988. Movements of Atlantic halibut (Hippoglossus hippoglossus) in the Canadian North Atlantic. Canadian Journal of Fisheries and Aquatic Sciences, 45: 484-491. https://doi.org/10.1139/ f88-058.

Themelis, D., and den Heyer, C. E. 2015. Catch of non-targeted species in Scotian Shelf and southern Grand Banks (NAFO Divisions 3NOPs4VWX5Z) Atlantic Halibut Longline Fishery. DFO Can. Sci. Advis. Sec. Res. Doc. 2015/042. Available at: http://waves-vagues.dfo-mpo.gc.ca/ Library/359600.pdf.

Trzcinski, M. K., and Bowen, W. D. 2016. The recovery of Atlantic halibut: a large, long-lived, and exploited marine predator. ICES Journal of Marine Science, 73: 1104-1114. https://doi.org/10.1093/icesjms/fsv266.

van Etten, J. 2018. gdistance: Distances and routes on geographical grids. R package version 1.2-2. URL: https:// CRAN.R-project.org/package $=$ gdistance.

Venables, W. N., and Ripley, B. D. 2002. Modern Applied Statistics with S. Springer, New York. 498 pp.

Webster, R. A., Clark, W. G. Leaman, B. M., and Forsberg, J. E. 2013. Pacific halibut on the move: a renewed understanding of adult migration from a coastwide tagging study. Can. J. Fish. Aquat. Sci., 70: 642-653. https://doi.org/10.1139/ cjfas-2012-0371. 